УДК 94(477.8-11):338.486]"192/193"

\title{
ТУРИЗМ У СХІДНІЙ ГАЛИЧИНІ В МІЖВОСННИЙ ПЕРІОД: ІСТОРИКО-ЕКОНОМІЧНИЙ АСПЕКТ
}

\author{
Роман МАСИК \\ Львівський національний університет імені Івана Франка \\ кафедра історичного краєзнавства \\ вул. Університетська, 1, Львів, 79000, Україна \\ e-mail: krajeznawec@gmail.com
}

\begin{abstract}
Розглянуто стан туризму в міжвоєнній Польщі, головно в Східній Галичині. Проаналізовано формування правових норм, які регулювали туристичну справу. Визначено вплив держави, місцевого самоврядування і громадських організацій на розвиток туризму. Виокремлено проблеми туристичної справи в Польщі й Східній Галичині, зокрема, в міжвоєнний період: відсутність належної організації, достатньої реклами, туристичних провідників і карт (особливо чужими мовами), інвестицій, належної комунікації з курортами, нормального санітарного облаштування оздоровниць та ін. Показано дії влади і громади, щоб вирішити ці проблеми.

Ключові слова: туризм, Східна Галичина, міжвоєнний період, Ліга Підтримки Туризму, Відділення туризму, “популярні потяги”.
\end{abstract}

Дослідження досвіду минувшини туризму є важливим, щоб зрозуміти як краще нині організовувати відпочинок. Тим більше, для організації його в таких придатних для цього регіонах, яким є Галичина. Історія туристичної справи у міжвоєнній Польщі цікавила багатьох польських вчених ${ }^{1}$. Окремо історію туризму в Галичині проаналізував дослідник з Івано-Франківська Володимир Клапчук. Він головно описав історію деяких курортів в краї, проаналізував туристичну діяльність громадських організацій XIX - першої половини XX ст. ${ }^{2}$

Після відновлення польської державности туризм у Східній Галичині міг стати однією з прибуткових галузей місцевої економіки. В краї були добрі природні умови, красиві Східні Карпати, чимало історичних пам'яток, тому регіон мав усі можливості стати одним із туристичних центрів. Попри те, стан туризму тут був незадовільний. Це пояснювалося і недавньою війною, і тим, що колишня

\footnotetext{
${ }^{1}$ Leszek Ćwikła, Prawne aspekty rozwoju turystyki w Polsce w latach 1918-1939. (Lublin: KUL, 2011); Jerzy Gaj, Dzieje turystyki w Polsce. (Warszawa: Almamater, 2006); Idem. Zarys historii turystyki w Polsce. (Warszawa: Wyższa Szkoła Ekonomiczna, 2003); Piotr Gryszel, "Zarys historii turystyki w Polsce”, Lubuska Regionalna Organizacja turystyczna “Lotur”, отримано доступ 15 жовтня 2018 , http://www.lotur.eu/UploadFiles/524/178/1265187566-Historia_turystyki_w_Polsce_DOT_IT.pdf; Jacek Kraś, "Turystyka w Polsce w I połowie XX wieku", Kwartalnik Edukacyjny, (2009), No.1, 920; Władysław Krygowski, Zarys dziejów polskiej turystyki górskiej. (Warszawa: Sport i Turystyka, 1973); Zbigniew Kulczycki, Zarys historii turystyki. (Warszawa: Sport i Turystyka, 1977); Małgorzata Lewan, Zarys dziejów turystyki w Polsce. (Kraków: Proksenia, 2004).

${ }^{2}$ В. М. Клапчук, Туризм і курортне господарство Галичини. (Івано-Франківськ: Фоліант, 2012).
} 
ISSN 2078-6077. Наукові зошити історичного факультету Львівського університету. 2018-2019. Випуск 19-20. Proceedings of History Faculty of Lviv University. 2018-2019. Issue 19-20.

австрійська влада не належно використовувала туристичні можливості краю. Уряд Австро-Угорщини підтримував туристичний бізнес в інших регіонах держави (головно в австрійських і чеських землях), полишивши Східну Галичину лише для приватної ініціятиви ${ }^{3}$.

У міжвоєнній Польщі туризм зіткнувся з багатьма проблемами, які повною мірою не зуміли розв'язати. Майже за весь час існування II Речі Посполитої належно організувати туристичну справу не вдалося. Польська влада довго залишала ії на маргінесі ${ }^{4}$. Туристичним рухом опікувалося, за прикладом Франції і колишньої Австро-Угорщини, Міністерство Громадських Робіт (Ministerstwo Robót Publicznych). При ньому 1 липня 1919 р. сформовано Сектор туризму (Referat turystyki). Його очолив польський географ Мечислав Орловіч. Через обмеженість бюджету спочатку в Секторі працювали лише референт і його помічник. Саме тому запланували підрозділ розширити до спеціяльного відділу, де б трудилися кілька осіб, відповідальних за різні напрями туризму й туристичного промислу (колись так було в Австрії) туризму підпорядкували Загальному Департаментові (Departament Ogólny) Міністерства, а пізніше - Відділові Консервації Доріг Дорожнього Департаменту (Wydział Konserwacji Dróg Departamentu Drogowego)

Сектор мав дуже малий бюджет. Наприклад, у 1921 р. він склав лише 350 тис. польських марок. Ці кошти виділили головно на субвенції для туристичних й краєзнавчих товариств. Лише 20 тис. польських марок асигнували на видання путівника Польщею․ Від 1919 до 1924 р. бюджет Сектора складав від 100 до 7 тис. злотих на рік ${ }^{8}$. У 1925-1927 pр. фінансування Сектора зросло до понад 50 тис. злотих в рік. У наступні роки його бюджет продовжував зростати (1928 p. - 155 тис., 1929 - 190 тис., від 1930 р. - 240 тис. на рік). Загалом від 1919 до 1931 р. він складав в середньому 59,5 тис. злотих 9 .

Питання, пов'язані з туризмом, цікавили кілька міністерств, тому потрібно було створити орган, який би координував таку їх діяльність. Для цього в 1924 р. при Міністерстві Громадських Робіт створили Міжміністерську Туристичну Комісію (Międzyministerjalna Komisja Turystyczna). Ï̈̈ перше засідання відбулося

\footnotetext{
${ }^{3}$ Sprawozdanie z czynności oraz protokoty posiedzeń plenarnych Izby handlowej i przemystowej we Lwowie w roku 1926. (Lwów, 1927), 136.

${ }^{4}$ Mieczysław Orłowicz, "Turystyka w Polsce w 1921 roku”. Ziemia, No.1, (1921): 94.

${ }^{5}$ Piotr Gryszel, "Zarys historii turystyki w Polsce”, Lubuska Regionalna Organizacja Turystyczna “Lotur”, отримано доступ 15 жовтня 2018, http://www.lotur.eu/UploadFiles/524/178/1265187566Historia_turystyki_w_Polsce_DOT_IT.pdf; Informator turystyczny. (Warszawa: Drukarnia Artystyczna, 1932), 70; Małgorzata Lewan, Zarys dziejów turystyki w Polsce. (Kraków: Proksenia, 2004), 47; Mieczysław Orłowicz, "Organizacja państwowej opieki nad turystyką w Polsce”, Ziemia, No.8, (1926): 122 .

${ }^{6}$ Informator turystyczny. (Warszawa: Drukarnia Artystyczna, 1932), 71.

${ }^{7}$ Mieczysław Orłowicz, "Turystyka w Polsce w 1921 roku”, Ziemia, No.3, (1921): 99.

${ }^{8}$ Informator turystyczny. (Warszawa: Drukarnia Artystyczna, 1932), 71.

${ }^{9}$ Informator turystyczny. (Warszawa: Drukarnia Artystyczna, 1932), 72.
} 
5 березня 1925 р. Головою комісії став Мечислав Раппе. Вона збиралася тричотири рази на рік до 1928 р. Діяльність Комісії відродили ухвалою Економічного комітету Ради Міністрів 23 березня 1931 р. Від вересня 1928 до березня 1931 р. подібні функції виконувала Міжміністерська комісія для студій туризму (Międzyministerjalna Komisja dla zbadania zagadnień turystyki) при Міністерстві Фінансів (Ministerstwo Skarbu) ${ }^{10}$.

Поступово в Польщі ухвалювали право, яке регулювало справи туризму. Так, 23 березня 1922 р. видано закон про оздоровниці ${ }^{11}$. Дня 6 березня 1928 р. вийшло розпорядження президента Польщі про підтримку пам'яток ${ }^{12}$, a 10 березня 1934 p. ухвалено закон про охорону природи ${ }^{13}$.

Від 1931 р. уряд все більше звертав увагу на туризм, усвідомлюючи його значення для економіки, й почав проєктувати право схоже та те, що вже діяло в Західній Европі, де туристичний рух був розвинутий. Воно мало замінити закон, прийнятий у 1922 р. Дня 17 березня 1931 р. у Варшаві з ініціятиви Міністерства Громадських Робіт відбувся з'їд в справі підтримки туризму й туристичного промислу. Там спеціяльно обговорили джерела поповнення фінансів на розвиток туризму й організаційні справи. Невдовзі Союз Промислово-Торгових Палат (Związek Izb Przemysłowo-Handlowych) отримав проєкт закону про підтримку туризму. Проблемою було те, що він з'явився в несприятливий час кризи й передбачав нові податки на туризм. Господарське середовище мало багато застережень до проєкту. Зокрема, вважали, що не можна стягувати нові податки 3 промисловости і торгівлі на користь туризму. Переконували, що закон буде дієвий лише тоді, коли туристичний промисел матиме доступ до дешевих кредитів, отримуватиме нові інвестиції і коли централізують державні кошти, визначені для туризму. Також спротивилися наміру підпорядкувати туризм урядові й не підтримали ідею заснувати спеціяльне Державне Туристичне Урядництво (Państwowy Urząd Turystyczny) й створити мережу підпорядкованих йому органів на місцях. Держава мала б контролювати туризм, а не керувати ним. Союз Промислово-Торгових Палат пропонував створити Державну Туристичну Раду (Państwowa Rada Turystyczna), яка б впливала на державну туристичну політику й складалася наполовину з урядового і господарського середовища. Також

\footnotetext{
${ }^{10}$ Informator turystyczny. (Warszawa: Drukarnia Artystyczna, 1932), 81-86; Małgorzata Lewan, Zarys dziejów turystyki w Polsce. (Kraków: Proksenia 2004), 48; Mieczysław Orłowicz, “Organizacja państwowej opieki nad turystyką w Polsce”, Ziemia, No.8, (1926): 123.

11 "Ustawa z dnia 23 marca 1922 r. o uzdrowiskach", Dziennik ustaw Rzeczypospolitej Polskiej, No.31, (1922), poz. 254; Piotr Gryszel, „Zarys historii turystyki w Polsce”, Lubuska Regionalna Organizacja turystyczna “Lotur”, отримано доступ 15 жовтня 2018, http://www.lotur.eu/UploadFiles/ 524/178/1265187566-Historia_turystyki_w_Polsce_DOT_IT.pdf.

12 "Rozporządzenia Prezydenta Rzeczypospolitej z dnia 6 marca 1928 r. o opiece nad zabytkami”, Dziennik ustaw Rzeczypospolitej Polskiej, No.29, poz. 265.

13 "Ustawa z dnia 10 marca 1934 r. o ochronie przyrody", Dziennik ustaw Rzeczypospolitej Polskiej, No.31, poz. 274.
} 
ISSN 2078-6077. Наукові зошити історичного факультету Львівського університету. 2018-2019. Випуск 19-20. Proceedings of History Faculty of Lviv University. 2018-2019. Issue 19-20.

зауважив, що варто виокремити туристичні регіони (південно-західний гірський та морський), а не трактувати туристичною цілу державу ${ }^{14}$.

Закон про підтримку туризму так і не ухвалили. Після ліквідації Міністерства Громадських Робіт справи галузі 1 липня 1932 р. передали Міністерству комунікації. Там створили Відділ Загального Туризму (Wydział Turystyki Ogólnej) ${ }^{15}$. До заснування Державної Туристичної Ради справа дійшла аж у 1939 p. $^{16}$

Довго після відродження польської незалежности не влаштували управління туристичною справою на місцях. Спочатку запланували створити при воєводствах сектори туризму. Проте не було можливостей їх фінансувати. Саме тому Міністерство Громадських Робіт обмежилося рескриптом від 3 березня 1924 р., яким призначило урядників в своїх окружних дирекціях. В тих воєводствах, де дирекцій не існувало (наприклад, Тернопіль), їх функції перейняли урядники інших підрозділів воєводської управи. Вони відповідали за туризм і краєзнавство. У Львівському воєводстві урядниками були Зенон Лишик (19241926), Максиміліян Дудрик (1926-1931), Ян Весоловський (від 1931); Станиславівському - Ян Свобода (1928-1930) і Ромуальд Домбровський (від 1930); Тернопільському - Томаш Кунзек ${ }^{17}$.

Міжміністерська туристична комісія натомість 5 червня 1925 р. створила воєводські туристичні комісії, які запрацювали у вересні. Вони стали дорадчими органами при воєводствах. Ці комісії очолили директори громадських робіт ${ }^{18}$.

Навесні 1928 р. уряд офіційно вимагав від органів місцевої влади фінансово підтримувати туризм. Ефект цього був надто слабкий. Одні зовсім проігнорували звернення, інші виділили дуже мало грошей. Наприклад, Судова Вишня передбачила на туризм у бюджеті 1928/29 р. лише 10 злотих ${ }^{19}$.

Відсутність фінансів обмежила діяльність місцевої влади до обговорень проблем туризму й створення організацій, які мали шукати позабюджетні джерела його підтримки. Наприклад, у грудні 1929 р. під егідою Львівської воєводської управи заснували Малопольський Союз Підтримки Туризму (Małopolski Związek Popierania Turystyki). Подібну організацію створили і в

14 Львівське воєводське управління, м. Львів, Державний архів Львівської області (далі ДАЛО), ф. 1, оп. 18, спр. 1975, арк. 10зв.-18; Sprawozdanie z czynności Izby Przemystowo-Handlowej we Lwowie za rok 1931. (Lwów, 1932), 83-84; Sprawozdanie z czynności Izby Przemystowo-Handlowej we Lwowie za rok 1932. (Lwów, 1933), 105.

${ }^{15}$ Informator turystyczny. (Warszawa: Drukarnia Artystyczna, 1933), 31-32; Sprawozdanie z czynności Izby Przemystowo-Handlowej we Lwowie za rok 1932. (Lwów, 1933), 106.

${ }^{16}$ Stanisław Leszczycki, “Zadania i cele Państwowej Rady Turystycznej”, Turyzm Polski, No. 1, (1939): 1-4.

${ }^{17}$ Informator turystyczny. (Warszawa: Drukarnia Artystyczna, 1932), 87-89; Mieczysław Orłowicz, “Organizacja państwowej opieki nad turystyką w Polsce”. Ziemia, No. 9, (1926): 135.

${ }^{18}$ Informator turystyczny. (Warszawa: Drukarnia Artystyczna, 1932), 93; Mieczysław Orłowicz, “Organizacja państwowej opieki nad turystyką w Polsce”. Ziemia, No. 9, (1926): 136.

19 "Z turystyki”, Ziemia, No. 22, (1929): 402-403. 
Тернопільському воєводстві ${ }^{20}$. Дня 2 квітня 1933 р. відбувся I Воєводський краєзнавчий з'їзд Львівського воєводства ${ }^{21}$; 8-9 червня 1934 р. в Яремчі - збори, де обговорювали питання розвитку оздоровниць, курортів і туризму в Карпатах 22 і т. ін.

Місцеве господарське середовище наголошувало на перспективності туризму в Галичині. Наприклад, Промислово-торгова палата у Кракові вважала, що потрібно формувати туристичний регіон карпатського гірського хребта, який мав би мати пріоритетне значення для Польщі. Інвестиції в курорти і покращення умов для відпочивальників мали з часом збільшити їх число й створити нове джерело доходів до державного і місцевих бюджетів. Тоді ж наголосили, що розвиток туризму важливий не лише економічно, але й соціяльно, бо сприяє піднесенню народних промислів і мистецтва ${ }^{23}$.

Подібне зауважували і в господарському середовищі Східної Галичини, акцентуючи на ролі Львова для загальнопольського туризму, адже столиця краю - не лише історичний центр, а водночас і “брама” до Прикарпаття й низки прекрасних курортів (Великий Любінь, Немирів, Трускавець, Моршин) ${ }^{24}$.

Більше, ніж влада, справами туризму цікавилася громада. Східна Галичина стала одним із центрів громадського туристичного руху. Тут працювали різні туристичні й краєзнавчі організації: відділи Польського товариства Татрів (Polskie Towarzystwo Tatrzacskie) і Польського краєзнавчого товариства (Polskie Towarzystwo Krajoznawcze), бюро подорожей “Орбic” (biuro podróży “Orbis”), Товариство шанувальників минувшини Львова (Towarzystwo miłośników przeszłości Lwowa), “Плай”, “Чорногора” та ін. Вони пропагували туризм Східною Галичиною, налагоджували туристичні шляхи, виховували інструкторів й екскурсоводів, розвивали туристичний спорт, зокрема на каяках Дністром i Прутом. Проте, власних фінансів товариств було не достатньо, щоб істотно пожвавити туристичний рух ${ }^{25}$.

Найважче громадським організаціям було в перші роки після відродження польської державности. Після війни істотно впав курс польської марки й відсутність фінансів спричинила занепад багатьох провінційних туристичних гуртків, що активно працювали до $1914 \mathrm{p}^{26}$

${ }^{20}$ Sprawozdanie z czynności Izby Przemystowo-Handlowej we Lwowie za rok 1930. (Lwów, 1931), 165.

${ }^{21}$ Sprawozdanie z czynności oraz o stanie gospodarczym w okregu Izby Przemysłowo-Handlowej we Lwowie w roku 1933. (Lwów, 1934), 101.

${ }^{22}$ Sprawozdanie z czynności oraz o stanie gospodarczym w okręgu Izby Przemysłowo-Handlowej we Lwowie w roku 1934. (Lwów, 1935), 78, 102.

23 Львівське воєводське управління, м. Львів, ДАЛО, ф. 1, оп. 18, спр. 1975, арк. 8-9зв.

${ }^{24}$ Ibid. Арк. 2-7.

${ }^{25}$ Sprawozdanie z czynności oraz protokoły posiedzeń plenarnych Izby handlowej i przemystowej we Lwowie w roku 1926. (Lwów, 1927), 135; Sprawozdanie z czynności oraz protokoły posiedzeń plenarnych Izby handlowej i przemystowej we Lwowie w roku 1927. (Lwów, 1929), 139-140; Sprawozdanie z czynności Izby Przemystowo-Handlowej we Lwowie za rok 1930. (Lwów, 1931), 165; В. М. Клапчук, Туризм і курортне господарство Галичини. (Івано-Франківськ: Фоліант, 2012), 186-218.

${ }^{26}$ Mieczysław Orłowicz, “Turystyka w Polsce w 1921 roku”, Ziemia, No.3, (1921): 94. 
ISSN 2078-6077. Наукові зошити історичного факультету Львівського університету. 2018-2019. Випуск 19-20. Proceedings of History Faculty of Lviv University. 2018-2019. Issue 19-20.

У перші повоєнні роки необхідно було нагально об'єднати громадські туристичні організації. Першим кроком став з'їзд туристичних товариств, який відбувся 11-13 жовтня 1919 р. у Кракові. Там ухвалили створити Польський Союз Туристичних Товариств (Polski Związek Towarzystw Turystycznych). Водночас вирішили поділити компетенції між громадськими організаціями так, щоб вони не повторювалися. В березні 1920 р. запланували провести у Кракові організаційний з'їзд Союзу ${ }^{27}$. Однак, через дискусії поміж різними організаціями щодо поділу повноважень, ця справа надовго затягнулася. Уряд намагався самостійно це вирішити й з його ініціятиви 25-26 березня 1920 р. принаймні створили у Львові Польський Союз Оздоровниць (Polski Związek Zdrojowisk), що мав відбудувати і перебудувати знищені війною курорти ${ }^{28}$. Натомість, Польський Союз Туристичних Товариств організували аж 2-3 квітня 1927 p. Головою об'єднаної організації обрали депутата Станіслава Осєцького ${ }^{29}$. У вересні затвердили ії статут, а 5 лютого 1928 р. відбулося перше засідання Союзу ${ }^{30}$.

До половини 1930-х рр. розвиток туризму залежав від окремих громадських ініціятив. Хоч уряд почав більше допомагати галузі, але не мав коштів для належної її відбудови. Приватні ініціятиви дозволили сформулювати тоді теоретичні програми розвитку Карпат; краківське і львівське господарські середовища почали активніше наголошувати на прибутковості туризму в цьому perioнi. Проте, для істотних зрушень в галузі потрібні були державні інвестиції, зменшення чи звільнення від податків і т. ін.

У час економічної кризи 1930-х рр. займатися цією справою було надто складно. Чимало різних туристичних громадських організацій опинилися під загрозою банкрутства. Більшість закликів готувати нові кадри й видавати нові провідники й карти залишалися лише словами. Переважно тоді обмежилися організацією популяризаторських виставок. Наприклад, у квітні - травні 1931 p. відбулася туристично-краєзнавча та оздоровча виставка в Міському промисловому музеї у Львові ${ }^{31}$.

Лише 12 червня 1935 р., коли відносно стабілізувалися фінанси й господарство в Польщі, створено Лігу Підтримки Туризму (Liga Popierania Turystyki), яка стала

\footnotetext{
${ }^{27}$ Mieczysław Orłowicz, "Organizacja turystyki w Polsce”, Ziemia, No.3, (1920): 66-69; Mieczysław Orłowicz, "Turystyka w Polsce w 1921 roku”, Ziemia, No.3, (1921): 94-95.

28 "Polski Związek zdrojowisk we Lwowie", Ziemia, No. 5-6, (1920): 29-30, Małgorzata Lewan, Zarys dziejów turystyki w Polsce. (Kraków: Proksenia, 2004), 54.

${ }^{29}$ Informator turystyczny. (Warszawa: Drukarnia Artystyczna, 1932), 5. Mieczysław Orłowicz, "Zjazd towarzystw turystycznych w Warszawie", Ziemia, No.10, (1927), 158-159.

${ }^{30}$ Małgorzata Lewan, Zarys dziejów turystyki w Polsce. (Kraków: Proksenia, 2004), 55.

31 Львівське воєводське управління, м. Львів, ДАЛО, ф. 1, оп. 18, спр. 1975, арк. 6; Sprawozdanie z czynności Izby przemystowo-handlowej we Lwowie za rok 1931. (Lwów, 1932), 85.

${ }^{32}$ Piotr Gryszel, "Zarys historii turystyki w Polsce”, Lubuska Regionalna Organizacja turystyczna “Lotur”, отримано доступ 15 жовтня 2018, http://www.lotur.eu/UploadFiles/524/178/1265187566Historia_turystyki_w_Polsce_DOT_IT.pdf; Sprawozdanie z czynności oraz o stanie gospodarczym w okręgu Izby Przemystowo-Handlowej we Lwowie w roku 1935. (Lwów, 1936), 67.
} 
координувати галузь 32 . До ії складу ввійшло 12 делегатів організацій і товариств й 24 представники зацікавлених міністерств й територіяльного самоврядування. Ліга входила до Відділу Туризму Міністерства Комунікації ${ }^{33}$ Ця інституція, централізуючи капітали, які виникли 3 дрібних туристичних плат, отримала можливість інвестувати в більші туристичні центри. За підтримки Ліги по цілій Польщі виникла мережа союзів, які діяли за зразком французьких Синдикатів туристичної ініціятиви (Syndicat d'Initiativo), названі Союзами пропаганди чи Підтримки туризму. В організації тих союзів брали участь промислово-торгові палати, органи місцевого самоврядування і туристично-готельна промисловість. У 1936 р. засновано майже 20 союзів такого типу в польських містах, що пожвавило пропаганду і покращило обслуговування туристичних відділів на місцях. У Львові в 1935 р. для обслуговування туристичного руху створено Союз Підтримки Туризму (Związek Popierania Turystyki), який мав би забезпечити потреби туристичного руху, що постійно збільшувався в регіоні ${ }^{34}$.

У другій половині 1930-х рр. також активніше обговорювали туристичні можливості Прикарпаття. Зокрема, на засіданнях Господарської Ради Східної Галичини (Rada Gopsodarcza Małopolski Wschodniej) Станіслав Островський зауважував інвестиційні потреби міст регіону ${ }^{35}$. Регулярно відбувалися т. зв. Гірські з'їди. На одному з них, організованому в Сяноку 14-17 серпня 1936 р., обговорили економічну програму розвитку Прикарпаття. Водночас ухвалили створити Союз Гірських Земель (Związek Ziem Górskich), який би координував діяльність туристичних товариств у Сілезькому, Краківському, Львівському і Станиславівському воєводствах ${ }^{36}$. В 1938 р. у Східній Галичині організували два відділення Союзу - львівське і станиславівське ${ }^{37}$.

Крім неорганізованости, в міжвоєнній Польщі туризм зіткнувся з низкою інших проблем. До половини 1930-х рр. його не достатньо пропагували ${ }^{38}$. Це пов'язано з відсутністю загальнодержавних програм розвитку туризму. Пропагували спорадично, головно за участю туристичних і краєзнавчих товариств. Долучалося до цього й господарське середовище. Наприклад, у 1925 р. голова Польського Банку (Bank Polski) просив всі економічні організації, щоб вмовляли

${ }^{33}$ Małgorzata Lewan, Zarys dziejów turystyki w Polsce. (Kraków: Proksenia, 2004), 49.

34 Львівське воєводське управління, м. Львів, ДАЛО, ф. 1, оп. 18, спр. 2483, арк. 71; спр. 2577 , арк. 57-58; “Ankiety, konferencje i posiedzenia”, Wiadomości gospodarcze, No.8, (1937): 109. Sprawozdanie z czynności oraz o stanie gospodarczym w okręu Izby Przemystowo-Handlowej we Lwowie w roku 1936. (Lwów, 1937), 85.

35 Львівське воєводське управління, м. Львів, ДАЛО, ф. 1, оп. 18, спр. 843, арк. 155.

36 “Ankiety, konferencje i posiedzenie”, Wiadomości gospodarcze, No.16, (1936): 253.

37 Львівське воєводське управління, м. Львів, ДАЛО, ф. 1, оп. 18, спр. 2674, арк. 32, 84-85.

${ }^{38}$ Sprawozdanie z czynności oraz protokoły posiedzeń plenarnych Izby handlowej i przemystowej we Lwowie w roku 1926. (Lwów, 1927), 137.

39 "Posiedzenie plenarne Izby handlowej i przem. we Lwowie", Wiadomości gospodarcze, No.11, (1925), 168; Sprawozdanie z czynności oraz protokoty posiedzeń plenarnych Izby handlowej $i$ pzemystowej we Lwowie w roku 1925. (Lwów, 1926), 113. 
ISSN 2078-6077. Наукові зошити історичного факультету Львівського університету. 2018-2019. Випуск 19-20. Proceedings of History Faculty of Lviv University. 2018-2019. Issue 19-20.

своїх співробітників обмежити рекреаційні поїздки закордон ${ }^{39}$. Менше пропагувала туризм держава. Наприклад, у липні 1930 р. галузь репрезентовано на Міжнародній виставці комунікації і туризму, яка відбулася в Познані ${ }^{40}$. Стан справ змінився після утворення Ліги підтримки туризму. Вже в перший рік праці Ліга провела низку спеціяльних з'їздів: Зелені свята у Львові, Східні торги, Вітаємо армію у Львові і т. ін. В таких з'їздах взяли участь понад 30 тис. осіб. У 1936 р. в масовому туристичному русі, наприклад, у львівському воєводстві, взяло участь понад 70 тис. осіб (на 40\% більше у порівнянні з 1935 р.). У Ворохті завдяки підтримці Ліги і Туристичного відділення Міністерства комунікації запрацювало спеціяльне бюро туристичної обслуги ${ }^{41}$.

Розвиткові туризму заважало й те, що власники і працівники курортів здебільшого не мали відповідної освіти. Від цього якість послуг, які вони надавали, погіршувалася. Господарське середовище наголошувало, що вартувало передбачити, аби цією справою займалися лише добре навчені особи, які б могли належно обслуговувати пансіонати і готелі ${ }^{42}$.

Великою проблемою польського туризму було мале число туристичних провідників і карт (особливо чужими мовами) ${ }^{43}$. Створене в 1920 р. Бюро Закордонної Пропаганди (Biuro Propagandy Zagranicznej) планувало видати французькою й англійською мовами загальний провідник Польщею і декілька спеціяльних Львовом, Краковом, Познанню, Варшавою, Вільно і Татрами. У квітні 1921 р. Бюро закрили, а крім провідника Варшавою, інших не видано ${ }^{44}$.

Ще однією проблемою було не достатнє інвестування в туризм. До цього спричинилася головно нестабільність польської економіки. Постійні фінансові кризи негативно впливали й на туристичний бізнес. Влада суворо регламентувала вартість послуг, які надавали курорти, що не дозволяло розвиватися туристичному бізнесові. Господарське середовище погоджувалося, що це дещо захищало відпочивальника від невмотивовано високих цін. У галузі майже не було конкуренції, тому небагато власників курортів і оздоровниць могли “накручувати" ціни. 3 іншого боку, це заважало покращувати умови на курортах i в оздоровницях. Саме тому, туристичний бізнес просив владу дозволити піднімати ціни принаймні, коли пропонували для відпочивальників люксові умови ${ }^{45}$.

\footnotetext{
${ }^{40}$ Sprawozdanie z czynności Izby Przemystowo-Handlowej we Lwowie za rok 1930. (Lwów, 1931), 167.

${ }^{41}$ Sprawozdanie z czynności oraz o stanie gospodarczym w okręgu Izby Przemystowo-Handlowej we Lwowie w roku 1935. (Lwów, 1936), 68; Sprawozdanie z czynności oraz o stanie gospodarczym w okręgu Izby Przemystowo-Handlowej we Lwowie w roku 1936. (Lwów, 1937), 86.

${ }^{42}$ Sprawozdanie z czynności oraz protokoty posiedzeń plenarnych Izby handlowej i przemystowej we Lwowie w roku 1926. (Lwów, 1927), 137.

${ }^{43}$ Sprawozdanie z czynności oraz protokoły posiedzeń plenarnych Izby handlowej i przemystowej we Lwowie w roku 1926. (Lwów, 1927), 136.

${ }^{44}$ Mieczysław Orłowicz, “Turystyka w Polsce w 1921 roku”, Ziemia, No.3, (1921): 99.

${ }^{45}$ Sprawozdanie z czynności oraz protokoły posiedzeń plenarnych Izby handlowej i przemyslowej we Lwowie w roku 1926. (Lwów, 1927), 137.
} 
Розвиток туризму в міжвоєнній Польщі гальмували надто високі податки. Це відбувалося тоді, коли деякі країни регіону, які конкурували з польським туристичним бізнесом, істотно знижували податки для цієї галузі. Це дозволило, наприклад, угорським підприємцям акумулювати більше обігових коштів й інвестувати їх у свої курорти. Відповідно польський туризм ставав все менше спроможний конкурувати з угорським. Громадяни Польщі все частіше надавали перевагу гірським курортам сусідньої Угорщини ${ }^{46}$.

Господарське середовище Східної Галичини не одноразово зверталося до уряду, щоб скасував чи принаймні знизив податки для туризму. Подекуди, уряд стягував податки з підприємств галузі не аргументовано. Наприклад, підприємства, що займалися туризмом, сплачували за річні промислові свідоцтва, хоч працювали сезонно ${ }^{47}$.

До половини 1930-х рр. в туризм інвестували польські бізнес, різні туристичні й краєзнавчі товариства. Влада залишалася осторонь підтримки галузі аж до часу створення Ліги Підтримки Туризму. Після 1935 р. уряд таки почав інвестувати в туризм. До кінця 1937 р. по цілій Польщі з державного бюджету профінансовано різні проєкти галузі на 1,5 млн. злотих. У Східній Галичині відкрито нові готелі у Славську і Сянках; у Ворохті збудували дім для бюро обслуговування Ліги підтримки туризму ${ }^{48}$.

Відсутність належних інвестицій в туризм відображена також в тому, що 3 багатьма місцевостями (головно в гірських районах), сприятливими для відпочинку, довго не було належного сполучення. Покращувати стан справ взялися лише на початку 1930-х рр. Це пов'язано з розвитком моторизації в Польщі. Тоді збільшилося число автобусних перевезень до Немирова, Моршина, Косова, Трускавця та інших туристичних центрів ${ }^{49}$. В той самий час почали використовувати можливості Дністра і Пруту. Це сприяло розвитку туристичного спорту (плавання на каяках) ${ }^{50}$.

Розвиток туризму гальмували також високі ціни на залізничні квитки й недостатнє число туристичних маршрутів. Підприємці постійно наголошували, що необхідно запроваджувати знижки на подорожі залізницею ${ }^{51}$. Вперше до них

\footnotetext{
${ }^{46}$ Sprawozdanie z czynności oraz protokoły posiedzeń plenarnych Izby handlowej i przemysłowej we Lwowie w roku 1926. (Lwów, 1927), 137.

${ }^{47}$ Sprawozdanie z czynności Izby Przemystowo-Handlowej we Lwowie za rok 1932. (Lwów, 1933), 106.

${ }^{48}$ Sprawozdanie z czynności oraz o stanie gospodarczym w okręgu Izby Przemysłowo-Handlowej we Lwowie w roku 1937. (Lwów, 1938), 85.

${ }^{49}$ Sprawozdanie z czynności Izby Przemystowo-Handlowej we Lwowie za rok 1930. (Lwów, 1931), 166.

${ }^{50}$ Sprawozdanie z czynności Izby Przemystowo-Handlowej we Lwowie za rok 1930. (Lwów, 1931), 166; Sprawozdanie z czynności oraz o stanie gospodarczym w okregu Izby Przemystowo-Handlowej we Lwowie w roku 1935. (Lwów, 1936), 68.

${ }^{51}$ Mieczysław Orłowicz, "Turystyka w Polsce w 1921 roku”. Ziemia, No.3, (1921): 99; Sprawozdanie z czynności oraz protokoty posiedzeń plenarnych Izby handlowej i przemystowej we Lwowie w roku 1926. (Lwów, 1927), 136.
} 
ISSN 2078-6077. Наукові зошити історичного факультету Львівського університету. 2018-2019. Випуск 19-20. Proceedings of History Faculty of Lviv University. 2018-2019. Issue 19-20.

дослухалися 25 червня 1923 р., коли Міністерство Залізниці (Ministerstwo Kolei) видало відповідне розпорядження ${ }^{52}$.

На початку 1930-х рр. Міністерство комунікації почало активно цікавитися туризмом. Дня 1 квітня 1931 р. тут створено Відділення Туризму, яке очолив Ян Охман. Наприкінці того ж року сформували Окружні Туристичні Комісії Польської Державної Залізниці (Okręgowe Komisję Turystyczne Polskich Kolei Państwowych) ${ }^{53}$.

Від 1933 р. окружні залізничні дирекції запровадили спеціяльні “популярні потяги" 54 . Вони курсували від великих міст Польщі до туристичних центрів. Квитки на такі потяги були істотно дешевші, ніж на звичні ${ }^{55}$. Число таких потягів 3 кожним роком зростало. В 1934 р. Окружні Дирекції Польської Державної Залізниці у Львові і Станиславові запустили 55 “популярних потягів" $56 ; 1935$ р. 58 (перевезли 31403 особи; загалом в Польщі - майже 600 потягів перевезли понад 500 тис. туристів) ${ }^{57} 1936$ р. - 153 (перевезли 67692 особи) ${ }^{58} ; 1937$ р. -132 (перевезли 74465 осіб) ${ }^{59}$.

Відсутність інвестицій не сприяла покращенню комфорту в готелях, курортах i оздоровницях. В них часто не було води, санітарного і медичного обладнання ${ }^{60}$. Особливо гостро це відчували одразу після війни. Такі проблеми мали, навіть, відомі курорти. Наприклад, 5 серпня 1921 р. в Трускавці відбулося віче, яке скаржилося Міністерствові Громадського Здоров'я (Ministerstwo Zdrowia Publicznego) на жахливі санітарні умови в місцевих курортах. Міністерство сформувало спеціяльну комісію, яка перевірила стан справ і зобов'язала місцеву владу вирішити проблему. Однак, через фінансову кризу в державі й відсутність належних інвестицій тут усе довго залишалося без змін ${ }^{61}$.

52 "Ważne dla wycieczki”, Ziemia, No.9, (1923): 183-184.

${ }^{53}$ Informator turystyczny. (Warszawa: Drukarnia Artystyczna, 1932), 93-95.

54 Детальніше про “популярні” потяги див.: Iwona Kawalla-Lulewicz, "Pociaggi popularne” jako forma turystyki kolejowej w dwudziestoleciu międzywojennym", Zeszyty naukowo-techniczne SITK RP, Oddzial w Krakowie, No.3 (114), (2007): 45-59.

${ }^{55}$ Sprawozdanie z czynności oraz o stanie gospodarczym w okręgu Izby Przemystowo-Handlowej we Lwowie w roku 1933. (Lwów 1934), 73-74.

${ }^{56}$ Sprawozdanie z czynności oraz o stanie gospodarczym w okręgu Izby Przemystowo-Handlowej we Lwowie w roku 1934. (Lwów, 1935), 72.

${ }^{57}$ Sprawozdanie z czynności oraz o stanie gospodarczym w okręgu Izby Przemystowo-Handlowej we Lwowie w roku 1935. (Lwów, 1936), 67-68.

${ }^{58}$ Sprawozdanie z czynności oraz o stanie gospodarczym w okręgu Izby Przemystowo-Handlowej we Lwowie w roku 1936. (Lwów, 1937), 85-86.

${ }^{59}$ Sprawozdanie z czynności oraz o stanie gospodarczym w okręu Izby Przemystowo-Handlowej we Lwowie w roku 1937. (Lwów, 1938), 85.

${ }^{60}$ Sprawozdanie z czynności oraz protokoty posiedzeń plenarnych Izby handlowej i przemystowej we Lwowie w roku 1926. (Lwów, 1927), 136.

61 Львівське воєводське управління, м. Львів, ДАЛО, ф. 1, оп. 11, спр. 165, арк. 1-5; спр. 166, арк. $1-8,25$ 
На початку 1920-х рр. більшість курортів і оздоровниць Польщі не мали каналізації і водопостачання. Уряд намагався це вирішити повністю за рахунок власників курортів. Дня 19 листопада 1923 р. Міністерство Громадського Здоров'я видало розпорядження, де зобов'язало підприємців довести до ладу каналізацію і водопостачання за п'ять років ${ }^{62}$. Проте, вони не мали достатніх коштів; могли найдешевше взяти кредит в Банку Крайового Господарства (Bank Gospodarstwa Krajowego, що його визначив уряд надавати позики під низькі відсотки на розбудову курортів). При цьому амортизація позик мала відбутися за 10-15 років. Але ж для власників курортів уряд не створив умов, щоб вони могли швидко віддати кредити й працювати вже на прибуток ${ }^{63}$.

Обладнання оздоровниць у східній частині Галичини (крім Трускавця) поступалося тим, що розміщувалися в західній частині краю. Тут було менше належного лікарського обладнання, нормальних доріг, водопроводів і каналізації, мало-де провели електрику. 3 тієї причини курорти Східної Галичині були менше популярні ${ }^{64}$.

Водночас для гірського туризму бракувало спеціяльних станцій. Лише в другій половині 1930-х рр. Польське Товариство Татрів й інші громадські організації почали їх споруджувати ${ }^{65}$.

Переломовим моментом у вирішенні проблеми інвестицій в санітарне обладнання курортів став з'їзд Союзу Польських Оздоровниць, який відбувся на початку 1938 р. у Варшаві. Там передбачили інвестувати на п’ять років майже 62 млн. злотих у покращення стану тридцяти найбільших курортів (у 19281937 pр. польські оздоровниціі отримали майже 50 млн. злотих: 21,5 млн. державних і 28,5 приватних коштів) ${ }^{66}$.

Хоч у другій половині 1930-х рр. стан справ у польському туризмі покращився, однак багатії все ж надавали перевагу подорожам у чужі країни. Маркетингові кроки уряду, туристичних і господарських організацій не змогли того зупинити. Наприклад, у 1938 р. на прохання Ліги підтримки туризму Промислово-Торгова Палата у Львові просила своїх членів не відпочивати закордоном ${ }^{67}$. Туризм Карпатами зріс не через зростання популярности цього регіону як рекреаційної зони, а через збільшення доходів людности в Польщі.

\footnotetext{
62 "Rozporządzenie Ministra Zdrowia Publicznego z dnia 19 listopada 1923 r. w przedmiocie przepisów sanitarnych dla uzdrowisk, posiadających charakter, użyteczności publicznej”, Dziennik ustaw Rzeczypospolitej Polskiej, No.125, (1923), poz. 1016.

${ }^{63}$ Sprawozdanie z czynności oraz protokoły posiedzeń plenarnych Izby handlowej i przemystowej we Lwowie w roku 1926. (Lwów, 1927), 136-137.

${ }^{64}$ Sprawozdanie z czynności oraz o stanie gospodarczym w okręgu Izby Przemystowo-Handlowej we Lwowie w roku 1935. (Lwów, 1936), 71.

${ }^{65}$ Sprawozdanie z czynności oraz o stanie gospodarczym w okręgu Izby Przemystowo-Handlowej we Lwowie w roku 1937. (Lwów, 1938), 86.

${ }^{66}$ Ibid, 92-93.

67 Львівське воєводське управління, м. Львів, ДАЛО, ф. 1, оп. 18, спр. 2674, арк. 84.
} 
ISSN 2078-6077. Наукові зошити історичного факультету Львівського університету. 2018-2019. Випуск 19-20. Proceedings of History Faculty of Lviv University. 2018-2019. Issue 19-20.

За статистикою Союзу Польських Оздоровниць від 1919 до 1929 p. відвідуваність польських курортів зросла від 80127 осіб до 223303. У 1930 р. погіршилася кон'юнктура і число відпочивальників на польських курортах зменшилося до 198017 в 1931 р. Від 1932 р. постійно зростала відвідуваність, яка в 1936 р. сягнула 359759 (майже на 100\% більше у порівнянні з 1931 р.). Польща активно почала конкурувати з чужоземними курортами. Тут були одні 3 найменших цін в Европі ${ }^{6}$. Найпопулярнішими тоді курортами в Східній Галичині називали Трускавець, Немирів, Моршин, Великий Любінь. За підрахунками В. Клапчука, понад половину місць для відпочинку розміщувалися в Галичині. Регіон був найпопулярніший для внутрішнього туризму у II Речі Посполитій ${ }^{69}$.

Назагал, у міжвоєнній Польщі туризм довго перебував в кризі. До цього спричинилися відсутність державної стратегії його розвитку й належних інвестицій, недостатня підтримка галузі, погана інфраструктура, не врегульоване право і т. ін. До другої половини 1930-х рр. туризм Східною Галичиною чи не повністю залежав від приватних ініціятив. Лише наприкінці 1930-х рр. держава взялася нормувати відносини в туристичній справі, але до завершення цього не дійшло через початок Другої світової війни. Те, що влада II Речі Посполитої не належно використала економічні можливості Карпатського регіону, може бути для нинішніх України і Польщі уроком, що без державної підтримки й інвестицій втратимо шанс заробити на його природних можливостях.

\title{
TOURISM IN THE EASTERN GALICIA DURING THE INTERWAR PERIOD: HISTORICAL-ECONOMICAL ASPECT
}

\author{
Roman MASYK \\ Ivan Franko National University of Lviv, \\ Department of Local History \\ e-mail: krajeznawec@gmail.com
}

The main idea of the article is to analize the development of the tourism in the Eastern Galicia during the interwar period, to determine its progress and problems.

After the renovation of the Polish state in the Eastern Galicia the tourism became very profitable. It was promoted by: wonderful nature, beauty of the Eastern Carpathians and a lot of culturalhistorical centres. But the conditions of tourism were unsatisfactory, because of the late war and the previous Austrian state hadn't used the tourist possibilities of the Eastern Galicia. Austrian state wanted other parts of the empire to be visited by the tourists.

At the beginning of the Polish independence the most important problems of the tourism were: the lack of good connection (especially with mountainous regions), bad conditions at the hotels, health resorts (the absence of water, bad medical service), unorganized tourism, the lack of credits, few guides and maps (especially in foreign languages).

\footnotetext{
${ }^{68}$ Sprawozdanie z czynności oraz o stanie gospodarczym w okręu Izby Przemystowo-Handlowej we Lwowie w roku 1936. (Lwów, 1937), 90.

${ }^{69}$ В. М. Клапчук, Туризм і курортне господарство Галичини. (Івано-Франківськ: Фоліант, 2012), 13-14.
} 
Because of these problems rich people preferred to rest abroad, not in Poland. A lot of different actions for the increasing of the home tourism didn't help.

At that time Truskavets, Nemyriv, Morshyn, Velykyi Lubin were the most popular health resorts in the Eastern Galicia. It was considered that visiting Polish health resorts tourists could find out more about their native land, and to enrich the state budget.

The mergence decided all the problems of the tourist development till 1931. There were different tourist and ethnographical public organizations (The department of the Polish Society of the Tatr and Polish ethnographical society, travelling agency "Orbis", the Society of Lviv past admirers). They tried: to propagandize the tourism in the Eastern Galicia, to recover tourists' ways, to train guides. But it was difficult to increase the tourist movement because of the lack of finances.

From 1931 the state paid a great attention to the development of the tourism. But it was very complicated to deal with the tourism during the economic crisis of 1930-s A lot of different tourist public organizations became bankrupts. The most of attempts to train new staff, to publish new guidebooks and maps failed. Only specialized exhibitions were organized.

And in 1935 the Tourist Support Leaque was organized. At the same time the number of health resorts increased, the service was improved, new special tourists trains were started up. That's why the member of the tourists in the Eastern Galicia increased to 359759 persons in 1936 (1931 - 198017). Health resorts in the Eastern Galicia began to compete with foreign ones. By the way the prices for the rest were very low, and the conditions were quite normal. But the competition between the home and foreign tourism still remained. Rich people continued travelling and resting abroad. Marketing efforts of the government and different tourist and economical organizations couldn't influence the development of the home tourism. The tourism in the Carpathians increased because of the gradual improvement of the Polish people's living standarts.

In general, the tourism in Interwar Poland was in crisis for a long time. The Polish Government didn't properly use the economical resources of the Carpathian Region. Nowadays it's a good lesson for Ukraine and Poland - without the state support and investment every country can loose a chance to be enriched owing to natural resources.

Keywords: tourism, Eastern Galicia, Interwar period, the Tourism Support League, tourism branch, "popular trains".

\section{REFERENCES}

“Ankiety, konferencje i posiedzenia”, Wiadomości gospodarcze, No.8, (1937): 109; No.16, (1936): 253.

Ćwikła L. Prawne aspekty rozwoju turystyki w Polsce w latach 1918-1939. (Lublin: KUL, 2011).

Gaj J. Dzieje turystyki w Polsce. (Warszawa: Almamater, 2006).

Gaj J. Zarys historii turystyki w Polsce. (Warszawa:Wyższa Szkoła Ekonomiczna, 2003).

Gryszel P. "Zarys historii turystyki w Polsce", Lubuska Regionalna Organizacja turystyczna

"Lotur", accessed October 15, 2018, http://www.lotur.eu/UploadFiles/524/178/1265187566Historia turystyki w Polsce DOT IT.pdf

Informator turystyczny. (Warszawa: Drukarnia Artystyczna, 1932).

Informator turystyczny. (Warszawa: Drukarnia Artystyczna, 1933).

Kawalla-Lulewicz I. "Pociagi popularne" jako forma turystyki kolejowej w dwudziestoleciu międzywojennym", Zeszyty naukowo-techniczne SITK RP, Oddział wKrakowie, No.3 (114), (2007): 45-59.

Klapchuk V. M. Turyzm i kurortne gospodarstvo Galychyny. (Ivano-Frankivs'k: Foliant, 2012).

Kraś J. “Turystyka w Polsce w I połowie XX wieku”, Kwartalnik Edukacyjny, (2009), No.1, 9-20.

Krygowski W. Zarys dziejów polskiej turystyki górskiej. (Warszawa: Sport i Turystyka, 1973). 
ISSN 2078-6077. Наукові зошити історичного факультету Львівського університету. 2018-2019. Випуск 19-20. Proceedings of History Faculty of Lviv University. 2018-2019. Issue 19-20.

Kulczycki Z. Zarys historii turystyki. (Warszawa: Sport i Turystyka, 1977).

L'vivs'ke voyevods'ke pravlinnya, m. L'viv, Derzhavnyj arxiv L'vivs'koyi oblasti, f. 1, op. 11, spr. 165-166, op. 18, 2518, spr. 843, 1975, 2483, 2577, 2674.

Leszczycki S. “Zadania i cele Państwowej Rady Turystycznej”, Turyzm Polski, No. 1, (1939): 1-4.

Lewan M. Zarys dziejów turystyki w Polsce. (Kraków: Proksenia, 2004).

Orłowicz M. "Organizacja państwowej opieki nad turystyką w Polsce”, Ziemia, No.8, (1926): 122-124; No.9, (1926): 135-137.

Orłowicz M. “Turystyka w Polsce w 1921 roku”. Ziemia, No.1, (1921): 94-100.

Orłowicz M. "Zjazd towarzystw turystycznych w Warszawie”, Ziemia, No.10, (1927): 158-159.

"Polski Związek zdrojowisk we Lwowie", Ziemia, No.56, (1920): 29-30.

"Posiedzenie plenarne Izby handlowej i przem. we Lwowie", Wiadomości gospodarcze, No.11, (1925), 168;

"Rozporządzenia Prezydenta Rzeczypospolitej z dnia 6 marca 1928 r. o opiece nad zabytkami”, Dziennik ustaw Rzeczypospolitej Polskiej, No.29, poz. 265.

"Rozporządzenie Ministra Zdrowia Publicznego z dnia 19 listopada 1923 r. w przedmiocie przepisów sanitarnych dla uzdrowisk, posiadających charakter, użyteczności publicznej”, Dziennik ustaw Rzeczypospolitej Polskiej, No.125, (1923), poz. 1016.

Sprawozdanie z czynności Izby Przemystowo-Handlowej we Lwowie za rok 1930. (Lwów, 1931).

Sprawozdanie z czynności Izby Przemystowo-Handlowej we Lwowie za rok 1931. (Lwów, 1932).

Sprawozdanie z czynności Izby Przemysłowo-Handlowej we Lwowie za rok 1932. (Lwów, 1933).

Sprawozdanie z czynności oraz o stanie gospodarczym w okręgu Izby przemystowohandlowej we Lwowie w roku 1933. (Lwów, 1934).

Sprawozdanie z czynności oraz o stanie gospodarczym w okręgu Izby przemystowohandlowej we Lwowie w roku 1934. (Lwów, 1935).

Sprawozdanie z czynności oraz o stanie gospodarczym w okręgu Izby PrzemystowoHandlowej we Lwowie w roku 1935. (Lwów, 1936).

Sprawozdanie z czynności oraz o stanie gospodarczym w okregu Izby PrzemystowoHandlowej we Lwowie w roku 1936. (Lwów, 1937).

Sprawozdanie z czynności oraz o stanie gospodarczym w okregu Izby przemystowohandlowej we Lwowie w roku 1937. (Lwów, 1938).

Sprawozdanie z czynności oraz protokoty posiedzeń plenarnych Izby handlowej $i$ pzemysłowej we Lwowie w roku 1925. (Lwów, 1926).

Sprawozdanie z czynności oraz protokoty posiedzen plenarnych Izby handlowej $i$ przemystowej we Lwowie w roku 1926. (Lwów, 1927).

Sprawozdanie z czynności oraz protokoty posiedzeń plenarnych Izby handlowej $i$ przemystowej we Lwowie w roku 1927. (Lwów, 1929).

"Ustawa z dnia 10 marca 1934 r. o ochronie przyrody", Dziennik ustaw Rzeczypospolitej Polskiej, No.31, poz. 274.

"Ustawa z dnia 23 marca 1922 r. o uzdrowiskach", Dziennik ustaw Rzeczypospolitej Polskiej, No.31, (1922), poz. 254;

"Ważne dla wycieczki", Ziemia, No.9, (1923): 183-184.

“Z turystyki”, Ziemia, No.22, (1929): 402-403. 